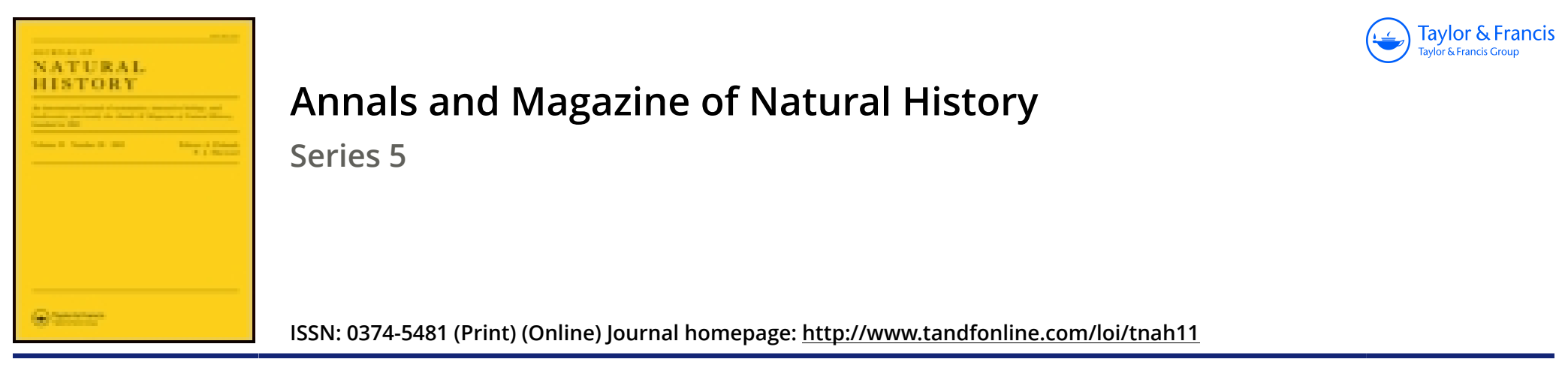

\title{
XVII.—On some Histeridæ new to the Japanese fauna, and notes of others
}

\section{George Lewis}

To cite this article: George Lewis (1884) XVII._-On some Histeridæ new to the Japanese fauna, and notes of others, Annals and Magazine of Natural History, 13:74, 131-140, DOI: 10.1080/00222938409459212

To link to this article: http://dx.doi.org/10.1080/00222938409459212

$$
\text { 册 Published online: } 07 \text { Oct } 2009 .
$$

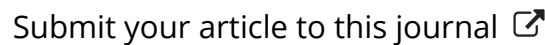

Џ Article views: 4

Q View related articles $\sqsubset$

4 Citing articles: 3 View citing articles 진 


\section{XVII.-On some Histeridæ new to the Japanese Fauna, and Notes of others. By GEoRge Lewis.}

Is 1879, twenty-six species of Histeridæ were recorded from Japan, and the present paper treats of twenty-three more. Besides these, there are fourteen species of Paromalus and seven of Saprinus to be determined, which will bring the Japanese species up to about seventy, when all those contained in my collection are recorded; and it is hardly likely that this list will be much augmented at present, as the rarer Histeridæ are very local, and those which associate with Formicidx are difficult to find. The eight species marked with an asterisk are such as have allies in the tropical parts of Eastern Asia; the others agree with the Histeridæ of Europe and Northern Asia. The species of Tryponceus are worthy of notice, because one of them occurs as far north as latitude $43^{\circ}$, and hitherto Mexico has been the most northern country from which any species has been recorded.

I failed to find Teretrius in Japan; but it is the only genus likely to be found in the archipelago which is not as yet represented in the list. Hister quinquestriatus, Motsch., given in my 'Catalogue' as no. 663, I now consider =duodecimstriatus, Schrank, and Onthophilus striatus, F. (? var. Harold), no. $676,=$ flavicornis, Lewis.

In the Histeridæ, as in other families, some of the species from Japan are closely allied to European forms, and I think we cannot refuse to admit the probability of a common origin for both at no very remote period; so that a close comparison and careful study of such insects as Hololepta plana and depressa, Hister unicolor and concolor, or Hetcerius gratus and ferrugineus, will perhaps show the direction that modification may assume in like forms when isolation is fairly complete, as in Japan, and the conditions realized within the area are sufficiently potent to produce a visible effect. It may be said that it is only incidentally that Hister concolor and Hololepta depressa can be distinguished from their European congeners by a densely punctured pygidium : but the incident does not lie simply in their having it; it lies in the fact that both from their habits have been subjected to certain conditions which cause such sculpture.

The most essential differences between any part of Europe and Japan are shown in the climate and other physical conditions, which in the latter country nourish great forests of magnificent timber even at fairly high altitudes, while in 
Europe forests relatively occupy an insignificant area, and such trees as grow in favourable situations never attain to the vigour and consequent stature of those in the East.

\section{List of Species, arranged generically.}

Hololepta depressa, n, sp.

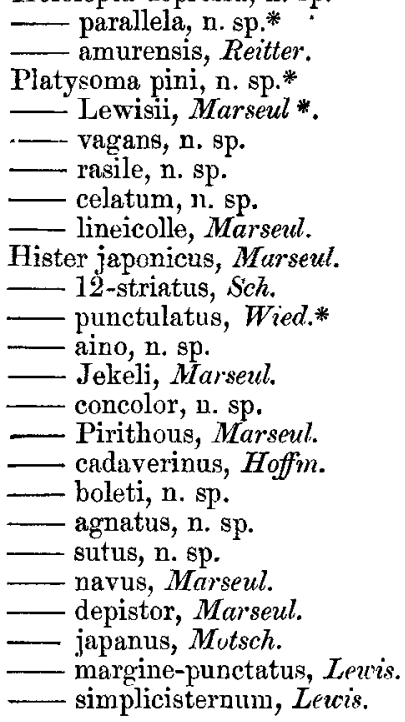

Carcinops 14-striata, Steph.

Epierus lucûs, n. sp.

Paromalus musculus, Marseul.

Notodoma fungorum, n. sp.*

Hetærius gratus, $n$. sp.

- optatus, n. sp.

Dendrophilus Xavieri, Marseul.

Triballus semen, $\mathrm{n}$. sp.

Saprinus speciosus, $E r$.

- pecunius, Marseul.

- nitidus, Payk.

_- sinæ, Marseul.

Gnathoncus rotundatus, $I l l$.

Tryponæus fagi, n. sp.**

venator, $\mathrm{n} . \mathrm{sp}$.*

Plegaderus Marseuli, Reitter.

Onthophilus flavicornis, n. sp.

-.._ ostreatus, Lewis.

- silvæ, n. sp.

- arboreus, $n$. sp.*

Abræus bonzicus, Marseul.

Bacanius niponicus, Lewis.

Acritus Komai, Lewis.

Myrmidius ovalis, Beck.

The new species are :-

\section{Hololepta depressa, n. sp.}

H. plance proxime affinis, nigra, nitida; pronoto stria marginali tenuissima ; elytris striis 2 dorsalibus abbreviatis ; pygidio dense punctato. I. $6 \frac{1}{2}$ mill.

Exceedingly like the European $H$. plana; the head and prosternum are both narrower, and the pygidium thickly and rather coarsely punctured.

Distributed sparingly from the Kumagawa in Higo to the Ishikari river in Yezo. All the specimens taken were resting under bark, and generally on the lateral branches 12 or 14 feet from the ground.

\section{Hololepta parallela, $\mathrm{n} . \mathrm{sp}$.}

H. elongutce proxime affinis, parallela, valde plana, nigra, lævissima; fronte non tuberculata; elytris stria subhumerali brerissima; 
abdomine subtus plano: propygidio utrinque sulcato, pygidio impunctato. L. 7 ad 8 mill.

This species is like H. elongata, but it has no tuberele on the head, nor is there an arched sulcns in the third (the broadest) segment of the abdomen beneath. The sides of the thorax are more rotundate, and each elytron has one short stria at the base. These characters, joined to the broader outline and facies generally, are of good specific value.

I obtained a series of twenty specimens in the moist forests of Higo in May, chiefly at Konose and Yuyama; it is the most tropical form of the genus in Japan, and is found under the bark of both the hard-wooded evergreens and the deciduous trees.

\section{Hololepta amurensis, Reitter.}

Hololepta amurensis, Reitter, Deutsche ent. Z. xxiii. (1879) p. 213.

The male of this species has a deep thoracic fossa. It was described by Herr E. Reitter from Amurland, as the trivial name indicates, and I found it commonly in all the forests of Japan of moderate elevation. I have beaten it in plenty near the Junsai lake in August, off the branches of Salix infested with Cossus.

Note.-Some of the Histerids of the Hololepta group with simple mandibles are not strictly entomophagous in the imago state; and this is particularly the case with H.amurensis, which, I believe, feeds exclusively on exuding sap. Hololepta elongata, which I have taken plentifully in Ceylon and other places, is probably (with $H$. parallela) wholly dependent on small soft-bodied larvæ for food, and I have never seen $H$. depressa at sap.

\section{Platysoma pini, n. sp.}

Ovale, subconvexum, nigrum, nitidum, læve: fronte clypeoque concavis, stria transversa integra; pronoto stria non interrupta; elytris striis 1-4 integris, 5 breviori, 6 nulla; propygidio biimpresso, pygidio margine elevato, grosse punctatis; antennis pedibusque brunneis. L. 5 mill.

Closely allied to H. odiosum (Marseuli, Cand.), but smaller ; with a different system of dorsal striation.

Occurs under pine-bark in the warmer parts of Japan; Higo and Isei are the chief localities for it.

Platysoma vagans, 1. sp.

Oblongum, parallelum, subconvexum, nigro-piceum; fronte subconcava, stria recta; pronoto punctulato, stria integra; elytris 
striis 1-3 integris, 4-5 abbreviatis, 6 nulla ; propygidio pygidiogue grosse punctatis et immarginatis ; pedibns rufis. L. $4 \frac{1}{2}$ mill.

This species comes near to P. Lewisii; it is less convex, more parallel, with the fourth and fifth striæ shortened from the middle; the pygidium is emarginate and convex.

I obtained it from an oak near Bibi, in Sonth Yezo, August 16, 1880.

\section{Platysoma rasile, n. sp.}

Oblongum, subparallelum, depressum, nigrum, nitidum, læve ; fronte concava, stria integra; pronoto lateribus sparse punctatis, stria pone oculos utrinque angulata; elytris striis 1-3 dorsalibus integris, 4-5 abbreviatis; propygidio pygidioque fortiter punctatis. L. $3 \frac{1}{2}$ mill.

This species is very close to $P$. Lecontei; it is more parallel and less quadrate, but the general sculpture above is almost identical. Beneath, the segments of the abdomen are of equal breadth, not contracted in the middle, as in P. Leconte $i$; and in this particular there is a like modification to that hereafter noticed between Hister Ariasi and Hister aino.

I took a few examples at Kumamoto and Konose in Higo.

Platysoma celatum, n. sp.

Oblongo-ovatum, nigrum, nitidum ; fronte subconcava, stria recta ; pronoto antice rufo, lateribus punctulatis, stria transversa interrupta; elytris striis 1-4 integris, 5 abbreviatis; propygidio pygidioque punctatis ; antennis pedibusque rufo-brunneis. L. 3 mill.

This species is allied to the preceding ( $P$. rasile), but the striation is different and also the coloration.

Occurs in the vicinity of Yokohama in "fir-stools" early in spring.

\section{Hister aino, n. sp.}

Ovalis, convexus, niger, nitidus; pronoto lateribus late punctatis, stria integra, margine angusto, elevato ; elytris striis'1-4 dorsalibus integris, quinto et suturali abbreviatis ; propygidio sparse punctato, utrinque subfoveolato, in medio linea longitudinali distincta; pygidio dense et grosse punctato. L. 8 mill.

This insect in its general sculpture agrees with the rare European $H$. Ariasi, but it has not the subparallel outline of that species. This shortness or more ovate form as compared with $H$. Ariasi arises from the structure of the abdominal segments. In $H$. Ariasi, the segments of the abdomen beneath are of equal breadth; in II. aino, the three median segments are narrow and only clearly visible at the sides, for in the 
middle they are soldered together, and a few punctures alone remain to indicate their limits. The broad lateral band of punctures on the thorax separates it from all the other Histerids in Japan; but it may be plaeed in the catalogue near H. Jekeli.

This peculiar Hister has been found in the district of the Ishikari river in Yezo.

\section{Hister concolor, n. sp.}

Ovalis, subconvexus, niger, nitidus; fronte stria integra; pronoto stria laterali externa valde, interna vix abbreviatis; elytris striis 1-3 integris, 4-6 brevibus ; propygidio subfoveolato pygidioque dense et grosse punctatis. L. 8 mill.

$H$. concolor is sculptured like $H$. unicolor, except on the two abdominal segments seen from above, which are strongly and closely punctured. In its general facies it is like H. 4-notatus, being wider and less convex than $H$. unicolor, and the interstice between the inner thoracic stria and the outer margin is wider and the short stria is more in the centre of this interstice.

This is also from the vicinity of the Ishikari river.

Note.-I found three specimens of Hister japanus, Motsch., on the beach at Yokohama; it comes near H.4-notatus, Scriba.

\section{Hister boleti, n. sp.}

Ovalis, convexus, niger, nitidus ; fronte plana, stria integra profunde impressa ; pronoto striis punctatis, stria pone oculos utrinque deflexa ; elytris striis crenatis, $1-3$ dorsalibus integris, 4,5 , et suturali brevibus; propygidio subfoveolato pygidioque punctatis; mesosterno leviter sinuato. L. 7 mill.

This species is the size of $H$. cadaverinus, but in general sculpture comes nearest to the rare European $H$. distinctus. From the latter, the longer mandibles, the remarkable deflexure in the thoracic stria behind the eyes, the fourth dorsal stria not reaching the middle, and the sinuate mesosternum (as in H. cadaverinus) are good distinguishing characters.

It occurs commonly at Chiuzenji in an arboreal fungus, and $I$ also obtained it at Kashiwagi in the Kii peninsula.

\section{Hister agnatus, n. sp.}

Ovalis, subconvexus, niger, nitidus ; pronoto striis lateralibus integris, postice approximatis; elytris striis 4 dorsalibus integris, 5 et 6 abbreviatis ; prosterno impunctato. L. 5 mill.

This species is almost identical with $H$. cadaverinus as regards sculpture, but it is much less convex. It is not larger than $H$. foedatus, which it resembles in the structural plan of its 
abdominal segments and also in its outline. Hister foedatus and marginicollis, with $H$. aino and agnatus, have segments $2-4$ of the abdomen much contracted in the middle; and the result of this is that the pygidium is reflexed by being drawn up towards the sternum.

I obtained my specimens from a dead fowl, set as a trap for necrophagous insects, at Nikko, in the forest behind the temples, in June 1880.

\section{Hister sutus, n. sp.}

Suborbicularis, convexiusculus, niger, nitidus; stria frontali subtransversa; pronoto subtiliter et parce punctulato; elytris striis 1-3 integris, 4 ante basin abbreviata, 5 et 6 ante medum terminatis; prosterno basi bistriata; mesosterno sinuato, margine punctato-striato. L. 4 mill.

This species is of the same stature as $H$. ruficornis, and possesses some of its characters, but the two thoracic striæ bring it into the H. cadaverinus group.

It is apparently rare. I obtained only four specimens from the elevated forest above Kiga, near Miyanoshita, in May 1880 .

\section{Epierus lucĥs, n. sp.}

Ovalis, parum convexus, niger, nitidus; antennis rufis, pedibus piceis; pronoto punctulato; elytris striis 5 dorsalibus et suturali integris; propygidio pygidioque dense punctatis. L. $2 \frac{1}{2}$ mill.

Larger and more ovate than $E$. comptus; the head is very finely punctured, with a transverse stria between the eyes. The thorax is clearly punctate, and rather thickly so at the base, in front of the scutellum; the interstices of the elytral stria are all finely punctured.

The type of this species came from a rotten tree in the grounds of the Kasuga no Miya, at Nara, June 1881, and I believe all the species of this genus are of arboreal habits. I have only one specimen.

\section{Notodoma fungorum, n. sp.}

Globosum, rufo-castaneum, nitidum, punctatum; elytris punctatostriatis, 1, 2 et 4 integris, 4 antice cum suturali arcuatim juncta ; tibiis multispinosis. L. $3 \frac{1}{2}$ mill.

When in Paris, I carefully compared this species with Marseul's type of $N$. globatum from India, and found it distinct, but closely allied. The size is larger and the punctuation more coarse, and there is a slight difference in the form of the striæe. On the humeral angle, and in the space between the second 
and fourth stria at the base of each stria, there is a large cream-coloured blotch; this, with the prevailing red colour of the species, is a very remarkable feature for the family.

It is not uncommon in all the islands, infesting fungi on trees, which it visits in the first stage of decomposition, when there is an abundance of other insects, on the larvæ of some of which it doubtless feeds.

Hetoerius grotus, n. sp.

Subquadratus, rufo-brunneus, fulvo-hispidus; fronte lateribus striatis; pronoto utrinque bisulcato; elytris striis 3 distinctiy, 3 brevi; pygidio paree punctato, tenuissime impresso. $\mathrm{L}$. $1 \frac{1}{2}$ mill.

This species is very closely allied to H. ferrugineus; it is darker in colour, balf as large again, with legs relatively much longer and tibiæ much more dilated. The elytral striæ are three in number, two complete, and the third only as long as two thirds of the elytra.

I took this species with a fuscons-coloured ant, midway between Shimonosuwa and the Wada-toge, August 1, 1881.

Hetcerius optatus, n. sp.

Oblongo-ovatus, nigro-piceus, sparse fuscescenti-hirtus, punctulatus ; pronoto lateribus subrotundatis, margine latissimo, medio bistriato; elytris striis 1-33 et suturali integris ; pedibus rufis, tibiis modice latioribus. I. 2 mill.

I have only a single example of this curious Hetcerius, which differs in colour and outline from all the hitherto recorded species. The whole insect is piceous black, save the anterior angles of the thorax and the legs, which are red. The thorax has the lateral margin very wide, with two short fine striæ in the centre; these lines are not, as may at first appear, the limit of the thoracic margin. The thorax, especially in the anterior portion, is much more coarsely punctured than the elytra.

I received this species from the vicinity of the Ishikari river, in Yezo, and with it came specimens of a genus of Synteliidæ (notyet enunciated), which correspouds with $C y$ listiv in the Histeridm, and it is probable that they all came from the same tree. I think, therefore, that $H$. optatus has been taken in association with an arboreal ant; and this idea seems confirmed by the colour of the species, which agrees somewhat with Dendrophilus punctatus or a dark-coloured Eretmotes.

Triballus semen, n. sp.

Ovalis, parum convexus, dense punctatus, nigro-piceus, parun Ann. d Mag. N. Hist. Ser. 5. Vul. xiii. 
nitidus ; fronte post oculos subtuberculata; elytris striis dorsalibus 2 abbreviatis, obsoletis. L. 2 mill.

Allied to T. americanus, but more convex, with the forehead behind the eyes more elevated, the elytra strigose-punctate at the sides, and the margin simple, not reflexed.

I have only one specimen; it was taken in an old tree at Kiga, near Miyanoshita, May 1880.

\section{Tryponceus fagi, n. sp.}

Cylindricus, niger, nitidus, undique punctatus; antennis pedibusque rufo-piceis. L. 4 mill.

¿. Frontis lateribus basisque margine elevatis; proncto antice retuso, medio subelevato.

q. Fronte plana, in medio depressa ; pronoto antice convexo.

$T$. kalemantenus is rather shorter and broader than this species, but the two are nearly allied. The prosternum in $T$. fagi has no lateral stria, and the thoracic marginal line continues well round the basal angles.

The perfect insects of Tryponceus prey on those of Platypus, and it is useless seeking for the former in trees not infested by the latter, which go 6 or 8 inches into the trees and are followed by the Histerids. It is impossible to say from observation whether the spines or processes on the apices of the elytra of the wood-borers protect them in any way from their enemies, but I think they do not, and that they have other uses. Tryponceus cannot turn round in the trees, but can move backwards or forwards in the narrow galleries with almost equal facility. It can only be caught, as a rule, when traversing the distance between two holes; but I have beaten stray specimens in summer.

\section{Tryponceus venator, $\mathrm{n} . \mathrm{sp}$.}

Niger, nitidus, filiformis, parum dense punctatus ; antennis pedibusque piceis; prothorace stria laterali integra, prosterno utrinque striato. L. $3 \frac{1}{2}$ mill.

$\delta$. Rostro apice modice reflexo, thorace antice linea in medio vix elevata.

․ Fronte excavata.

This species is more filiform than any other I know from Asia, and is remarkable for its cylindricity, because the eastern forms of the genus are usnally much more robust than the American species. T. venator feeds on a much smaller Platypus than 7 . fagi; each species preys, in fact, on an insect of its own girth. The male has the thorax a little longer than the female and slightly compressed at the sides. 
Found only in South Japan, at Yuyama and Konose, but it is not rare where it occurs.

\section{Onthophilus flavicornis, n. sp.}

Breviter ovalis, niger, subnitid us; antennis brunneis, clava flava; fronte in medio unicostata; pronoto dense strigoso, margine angusto, subelevato ; propygidio tricarinato. L. 2 mill.

The sculpture is very similar in every respect to that of the European O. striatus; the distinguishing characters are the colour of the antennæ, and the sides of the thorax being only very narrowly margined, and not elevated at the base. There is a slight difference also of outline, and some of my remarks on Hister concolor will apply to this species.

Taken from a fungus at Bukenji, near Yokohama, early in March 1880.

Onthophilus ostreatus, Lewis.

Onthophilus ostreatus, Lewis, Ent. Mo. Mag. xvi. 1879, p. 76.

This species, which is the largest yet known in the genus, was formerly only recorded from China. In the autumn of $1880 \mathrm{Mr}$. Pryer obtained a fair series near his bungalow at Yokohama, from refuse in a turnip field, and $I$ am indebted to him for four examples.

\section{Onthophitus silva, n. sp.}

Suborbicularis, niger, opacus; fronte triangulariter carinata; pronoto parce tenuissime punctato, costis octo validis, duabus tantum abbreviatis; elytris sutura, margine laterali costisque duodecim, elevatioribus. L. $2 \frac{1}{2}$ mill.

The outline of this species in the head and thorax resembles that of the American O. alternatus, but the insect is a little smaller. The thorax has eight costæ, six complete, two (the third from the margin on each side) very short, with the punctuation of the intervening spaces very scattered and shallow. The elytra have twelvecostæ complete and equally elevated, the suture and margin corresponding with them; the interstices have at intervals a transverse line-like puncture, but none of the longitudinal punctures which are so general in this genus.

Found under dead leaves at the Akinomiya, near the Suwa lake, July $31,1881$.

\section{Onthophilus arboreus, n. sp.}

Orbicularis, niger, hispidus, opacus; antennis clava ferruginea. 0 . hispido proxime affinis, sed minor. L. $1 \frac{1}{3}$ mill.

This insect has the dorsal punctures much less deep than in 
O. hispidus; it must, however, be observed that the species of this section of Onthophilus are very difficult to define, as, when in good condition, they are covered with minute spines and mud-like scales, and it is impossible to see the sculpture. As in the genus Dastarcus, the specific differences are very slight. All the hispid species are arboreal in habit; the specimens I have from Japan were residing in galleries of wood-borers, probably Tomicus, and were 8 or 10 inches from any orifice by which they could emerge. In Ceylon, I found O. hispidus in the same way, obtaining a large number in one tree; and M. Raffray, under similar conditions, found $O$. costipennis (also a hispid species) in the island of Zanzibar.

The locality for $O$. arboreus is the forest behind the large temple at Nara, in Hawatchi, where I took it in June 1881.

\section{PROCEEDINGS OF LEARNED SOCIETIES.}

\section{DUBLIN MICROSCOPICAL CLUB.}

February 15, 1883.

Magnetic Iron-Sand.-Dr. Frazer showed a specimen of magnetic iron-sand, of which the crystals were of brilliant adamantine lustre, and showed several modifications of the primary form : these displayed marked polarity when acted on by an artificial magnet, arranging themselves in bead-like strings.

Starch-granules (?) remaining in the Ash of Platinotype Photographic Paper.-Mr. Greenwood Pim showed a preparation of the ash of platinotype photographic paper after treatment with potass oxalate developer. Imbedded in the fibre of the paper were bright blue semitransparent bodies, somewhat rounded, and which dissolved in hot nitric and hydrochloric acids; but cold acid did not appear to produce much effect. They were considered to be a peculiar form of starch-granule in the sizing of the paper.

Nauplius-stage of Astacus.-Prof. Haddon showed the Naupliusstage of Astacus fiuviatilis, also the similar stage of a Cirripede for comparison.

Penium mufopellitum, Roy, from Connemara, exhibited, to show the Exfoliation of the external realdish Cortical Coating.-Mr. Archer showed examples from Connemara of Penium rufopellitum, Roy, a remarkable, if not very striking, Desmid. It is curious, as would seem, that this species has not been found out of the United King- 